\title{
Double-Face Activity of Resveratrol in Voluntary Runners: Assessment of DNA Damage by Comet Assay
}

\author{
Barbara Tomasello, Salvatore Grasso, Giuseppe Malfa, Stefania Stella, ${ }^{2}$ \\ Marco Favetta, and Marcella Renis ${ }^{1}$ \\ ${ }^{1}$ Department of Drug Sciences; ${ }^{2}$ Section of Hematology, Department of Biomedical Sciences; University of Catania, Catania, Italy.
}

\begin{abstract}
Voluntary runners are subjected to a massive increase in reactive oxygen/nitrogen species production, which can promote different oxidative stress-related diseases such as premature aging, neurodegenerative disorders, and cancer. The aims of this work were to evaluate the following in peripheral blood cells of voluntary runners: (i) DNA status; (ii) susceptibility to the in vitro insult induced by hydrogen peroxide $\left(\mathrm{H}_{2} \mathrm{O}_{2}\right)$ as a breaking agent; (iii) capabilities of 3,5,4'trihydroxystilbene (RESV) in counteracting DNA damage. Twenty-five male voluntary runners were compared with 20 sedentary men, as age-matched controls, and DNA status was evaluated with different versions of comet assay: alkaline, neutral, and Fpg enzyme-modified version to measure 8-OH-deoxyguanosine (8-oxo-dG) levels. The $\mathrm{H}_{2} \mathrm{O}_{2}$ and/or RESV treatments were performed directly on agarose-embedded cells (atypical comet assay). The results evidenced DNA damage and levels of 8-oxo-dG higher in runners than in sedentary control subjects. The runners' DNA was more prone to the in vitroinduced oxidative insult $\left(200 \mu \mathrm{M} \mathrm{H}_{2} \mathrm{O}_{2}\right)$ than that of the control group. Resveratrol $(100 \mu \mathrm{M})$, depending on the individual basal DNA status, was able to switch from antioxidant to pro-oxidant. Our results, on the one hand, validated the proposed in vitro experimental protocol in order to measure individual DNA status. On the other hand, our data point out the importance of monitoring the athletes' redox status before subjecting them to dietary supplementation treatment.
\end{abstract}

KEY WORDS: $\bullet$ athletes $\bullet$ DNA fragmentation $\bullet$ oxidative stress $\bullet$ polyphenols

\section{INTRODUCTION}

$\mathbf{R}$ EACTIVE OXYGEN/NITROGEN SPECIES (ROS/RNS) are constantly produced by oxidative mitochondrial/cellular metabolism in aerobic organisms. ROS/RNS are neutralized by orchestrated antioxidant, enzymatic, and nonenzymatic defense systems. ${ }^{1,2}$ However, in the presence of an imbalance of cellular redox state, due to either a massive increase in ROS/RNS production or a decrease in efficiency/quantity of antioxidant systems, an oxidative stress condition arises. ${ }^{3}$

Redox imbalance is believed to play a causative role in a plethora of unwanted effects or diseases, as well as premature aging; cardiovascular, hepatic, and neurodegenerative diseases; inflammatory conditions; obesity; cancer susceptibility; and cell death. ${ }^{2-5}$ These effects are exerted differently according to individual variability linked with genetic variants in oxidative stress-related genes, as single-nucleotide polymorphisms in some cytosolic and/or mitochondrial antioxidant enzymes. ${ }^{6}$

\footnotetext{
Manuscript received 30 June 2011. Revision accepted 07 October 2011.
}

Address correspondence to: Marcella Renis, Ph.D., Department of Drug Sciences, University of Catania, Catania 95125, Italy, E-mail: renis@unict.it
Regular aerobic exercise is well known to modulate redox condition and ameliorate quality of life, particularly in older people, in which it decreases morbidity and mortality. ${ }^{4,5}$ However, a body of literature data has demonstrated that long-term activities, having both elevated energy expenditure and high oxygen consumption, may promote ROS production and oxidative stress conditions, depending on duration and type of exercise, as well as on the individual's lifestyle and eating habits. ${ }^{5,7}$

Human biochemical markers of oxidative stress are usually measured in plasma and in blood cells by several methods. ${ }^{89}$ Recently, there has been growing interest in exercise-induced DNA damage due to its involvement in various diseases, including carcinogenesis and neurodegeneration. ${ }^{5,10,11}$

Previous studies have used a variety of experimental approaches to measure DNA status/damage, such as highperformance liquid chromatography, 8-OH-deoxyguanosine (8-oxo-dG) assay, micronuclei test, chromosome aberration, and sister chromatid exchanges. These methods require expertise handling large amounts of DNA and are not usually cost or time effective. ${ }^{11,12}$

Among these, comet assay is widely considered a feasible, sensitive, low-cost, and valuable tool in monitoring, both in vivo and in vitro, DNA status. This method 
also permits evaluating different kinds of DNA damage induced by endogenous and/or exogenous factors, as well as the effects of some antioxidant supplementations and therapies. ${ }^{11,13-15}$

Natural antioxidant molecules have been extensively considered in preventing and/or reducing oxidative stress and DNA damage. ${ }^{7,8,16}$ Among natural compounds, 3,5,4'-trihydroxystilbene (RESV), found in various plants, has attracted particular attention in the last decade for its innumerable properties. In fact, it exerts antioxidant, antiinflammatory, antiatherogenic, immunomodulator, chemopreventive, chemiotherapeutic, in vitro, and in vivo properties, as well as increased life span in yeasts, flies, and rats. ${ }^{17-19}$

There is, however, growing evidence that RESV exhibits pro-oxidant activities under some experimental conditions. ${ }^{20}$ Nonetheless, the precise mechanisms exerted by resveratrol on various targets still need to be better elucidated.

The purpose of this study was to validate a protocol as a useful tool in examining the same sample: (i) the global DNA status and its 8-oxo-dG level (alkaline, neutral, and Fpg-modified comet assay versions); (ii) the susceptibility of runners' DNA to hydrogen peroxide $\left(\mathrm{H}_{2} \mathrm{O}_{2}\right)$ in vitroinduced insult; (iii) the in vitro capability of RESV in influencing DNA status (atypical comet assay). As control samples, sedentary subjects were considered.

\section{MATERIALS AND METHODS}

Inclusion criteria for subject participation were 25 male runners and 20 sedentary controls, aged $54 \pm 8$, nonsmokers, and $\mathrm{VO}_{2 \max }$ value classified as having excellent fitness levels. Subjects were nourished with a Mediterranean controlled diet, free of antioxidant supplementation, for one month before being tested. The daily run occurred under the same environmental conditions, intensity, distance, and length of weekly training (Table 1).

Informed consent from all patients was obtained in accordance with the recommendations of the declaration of Helsinki.

Blood samples (70-90 $\mu \mathrm{L})$ were collected from each subject by finger pricks (in the group of marathon runners, 30 min after the end of daily physical activity), immediately added to $1 \mathrm{~mL}$ of solution $\mathrm{A}\left(\mathrm{Ca}^{2+} / \mathrm{Mg}^{2+}\right.$-free Hank's balanced salt solution, $20 \mathrm{mM}$ ethylenediaminetetraacetic acid [EDTA], and 10\% dimethyl sulfoxide, $\mathrm{pH}$ 7.5-7.7), and

Table 1. Subjects' Enrolled Characteristics

\begin{tabular}{lrrr}
\hline Characteristics & $\begin{array}{r}\text { Control } \\
(\mathrm{n}=20)\end{array}$ & $\begin{array}{c}\text { Group A } \\
(\mathrm{n}=8)\end{array}$ & $\begin{array}{r}\text { Group B } \\
(\mathrm{n}=17)\end{array}$ \\
\hline Age (years) & $54 \pm 8$ & $54 \pm 8$ & $54 \pm 8$ \\
Height (cm) & $167 \pm 5$ & $164 \pm 7$ & $164 \pm 7$ \\
Weight (kg) & $71 \pm 4$ & $68 \pm 3$ & $61 \pm 3$ \\
$\%$ Body fat & $17 \pm 4$ & $15 \pm 2$ & $12 \pm 3$ \\
Body mass index $_{V O_{2 \text { max }}(\mathrm{mL} / \mathrm{kg} / \mathrm{min})}$ & $27 \pm 2$ & $25 \pm 2$ & $22 \pm 1$ \\
Training (miles/week) & $39 \pm 2$ & $58 \pm 4$ & $56 \pm 3$ \\
\hline
\end{tabular}

centrifuged at $800 \mathrm{~g}$ for $10 \mathrm{~min}$. The pellet was suspended in $200 \mathrm{~mL}$ of phosphate-buffered saline $1 \times$, separated in five aliquots (each $40 \mu \mathrm{L}$ ), and stored at $-80^{\circ} \mathrm{C}$ for 10 days. ${ }^{14,21}$ DNA damage was measured by different comet assay versions: (i) alkaline and/or neutral typical version ${ }^{22}$ to identify different types of DNA damage; (ii) Fpg-modified version measures the 8-oxo-dG level ${ }^{14}$; (iii) atypical version was performed, adding $200 \mu \mathrm{M} \mathrm{H}_{2} \mathrm{O}_{2}$ and/or $100 \mu \mathrm{M}$ resveratrol directly on agarose-embedded whole blood cells, considered a vital system. ${ }^{15}$

Eighty microliters for each sample, suspended in $520 \mu \mathrm{L}$ of $0.5 \%$ low-melting-point agarose, was spread on a Trevigen microscope slide (20 wells) and allowed to set at $4{ }^{\circ} \mathrm{C}$ for $20 \mathrm{~min}$.

The tests were performed in duplicate (Fig. 1). The timing for the preparation of each slide was synchronized to simultaneously immerse all the samples in the freshly prepared lysis solution A $(2.5 \mathrm{M} \mathrm{NaCl}, 100 \mathrm{mM} \mathrm{Na} 2$ EDTA, $10 \mathrm{mM}$ Tris, $\mathrm{NaOH}$ [pH 10.0-10.5], and 1\% lauroyl sarcosine; $1 \%$ Triton $\mathrm{X}-100$ and $10 \%$ dimethyl sulfoxide were added directly before use) for $1 \mathrm{~h}$ at $4^{\circ} \mathrm{C}$.

The control samples were only processed for alkaline and Fpg versions as previously described for runners' samples (Fig. 1).

\section{Alkaline and neutral comet assay}

After lysis in solution A, the samples were maintained for $20 \mathrm{~min}$ in a high-pH buffer $\left(300 \mathrm{mM} \mathrm{NaOH}\right.$ and $1 \mathrm{mM} \mathrm{Na}_{2}$ EDTA [pH 13.1]) to promote DNA unwinding, and then electrophoresed in the same buffer at $0.7 \mathrm{~V} / \mathrm{cm}$ for $30 \mathrm{~min}$ for the alkaline version, and in buffer B $(90 \mathrm{mM}$ Tris-base, $90 \mathrm{mM}$ boric acid, and $2 \mathrm{mM} \mathrm{Na}_{2}$ EDTA [pH 8]) at $0.5 \mathrm{~V} / \mathrm{cm}$ for $20 \mathrm{~min}$ for the neutral version.

\section{Fpg-modified comet assay}

The Fpg FLARE ${ }^{\mathrm{TM}}$ assay kit (Trevigen, Inc., Gaithersburg, MD) was used to analyze 8-oxo-dG level, according to the manufacturer's protocol. Naked DNA (or nucleoid) was digested with Fpg DNA repair enzyme that recognizes and cuts the sites corresponding to oxidized guanine bases. For each sample, $35 \mu \mathrm{L}$ of agarose-embedded whole blood cell suspensions was dropped in duplicate on two different slides. After $20 \mathrm{~min}$ at $4^{\circ} \mathrm{C}$ in the dark, slides were immersed in a prechilled lysis solution (provided with the FLARE assay kit), at $4^{\circ} \mathrm{C}$ for $60 \mathrm{~min}$. After lysis, $100 \mu \mathrm{L}$ of enzyme dilution buffer and/or Fpg enzyme solution (prediluted 1:10 in REC $^{\mathrm{TM}}$ dilution buffer [Trevigen, Inc.]) was added to the samples and then placed in the humidity chamber at $37^{\circ} \mathrm{C}$ for $45 \mathrm{~min}$. The slides were immersed twice (10 min each) in prechilled alkaline electrophoresis solution $(0.3 \mathrm{M} \mathrm{NaOH}$ and $1 \mathrm{mM} \mathrm{Na}{ }_{2}$ EDTA [pH 12.1]), and then electrophoresed at $0.7 \mathrm{~V} / \mathrm{cm}$ for $20 \mathrm{~min}$.

\section{Atypical comet assay}

Atypical comet assay was performed, treating the agarose-embedded cells with $70 \mu \mathrm{L}$ of $100 \mu \mathrm{M} \mathrm{RESV}$ at $37^{\circ} \mathrm{C}$ 


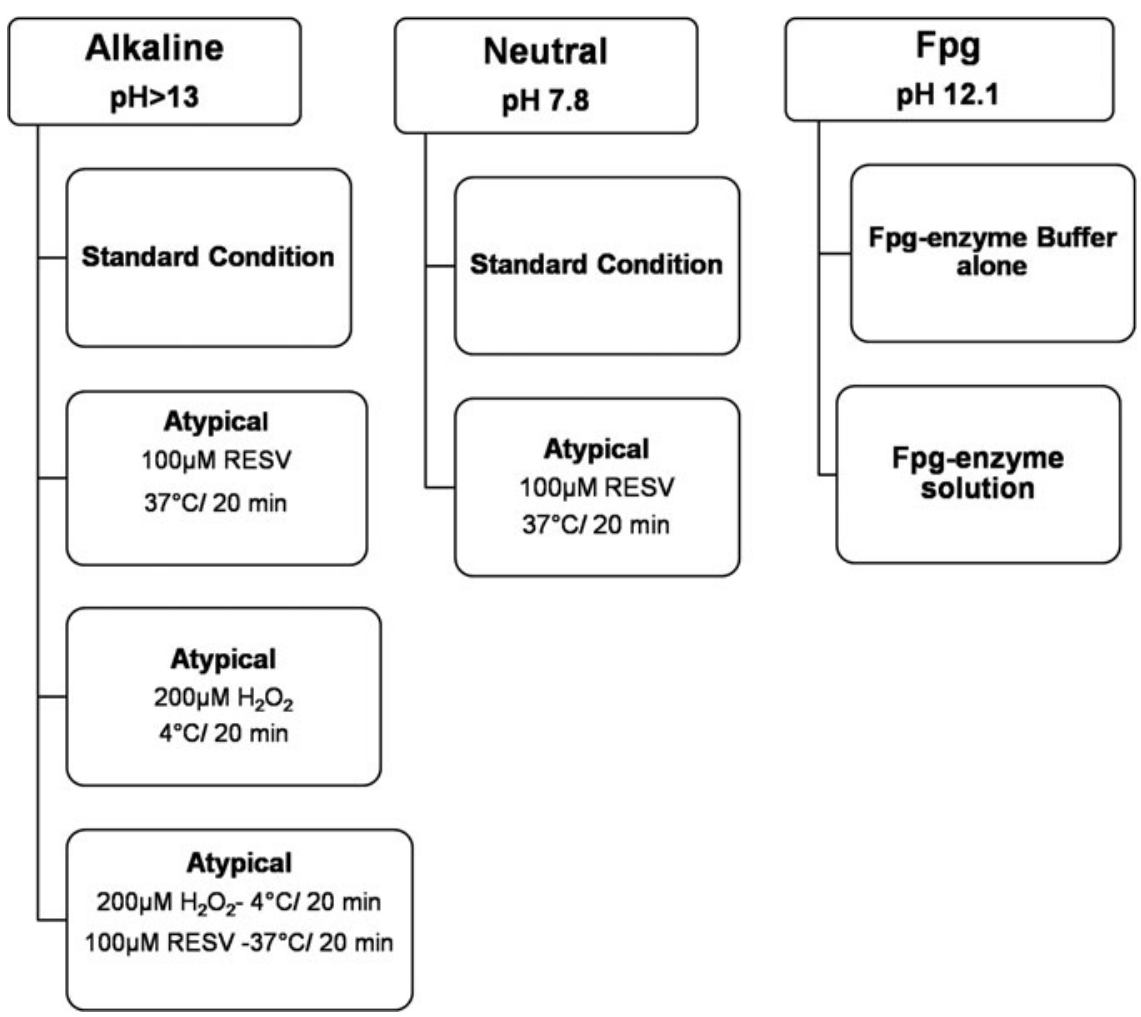

FIG. 1. The study design planned to evaluate DNA status/damage by the different types of comet assay.

for 20 min (Fig. 1), $200 \mu \mathrm{M} \mathrm{H}_{2} \mathrm{O}_{2}$ at $4^{\circ} \mathrm{C}$ for 20 min, or with $200 \mu \mathrm{M} \mathrm{H}_{2} \mathrm{O}_{2}$ plus $100 \mu \mathrm{M}$ RESV, as reported in Figure 1. Then, the slides were processed as reported for standard alkaline version. ${ }^{15}$

At the end of electrophoresis, all the slides were neutralized in the Tris buffer $(0.4 \mathrm{M}$ Tris- $\mathrm{HCl}$ [pH 7.5]), dehydrated with $70 \%$ ethanol, and stained with $40 \mu \mathrm{L}$ of Syber Green. One hundred nucleoids per sample (50 for each of the two replicates) were randomly analyzed using the Leika epifluorescence microscope (Leika, Wetzlar, Germany), interfaced with a computer. The percentage of damaged DNA in the tail of the comet (\%TDNA) was chosen as a parameter to measure DNA damage by the CASP free software. The data acquired by CASP were expressed also as a percentage of the values present in five different arbitrarily chosen classes, corresponding to different ranges of the \%TDNA values: I (undamaged cells: from $0 \%$ to $14 \%$ TDNA), II (low damaged cells: from $15 \%$ to $31 \%$ TDNA), III (moderate damaged cells: from $32 \%$ to $51 \%$ TDNA), IV (high damaged cells: from 51\% to 65\% TDNA), and V (very high damaged cells: $>65 \%$ TDNA). In addition, the values related to 8-oxo-dG level were also converted before hand to DNA break $/ 10^{9} \mathrm{Da} / \mathrm{Gy}$, standard units, obtained through an indirect calibration, according to Collins et al. ${ }^{23}$ and then as breaks $/ 10^{6}$ bp (altered bases $/ 10^{6}$ unaltered bases). ${ }^{24}$

The analysis, regardless of the electrophoretic conditions, did not include the lateral parts of the gel, the edges, superimposed comets, and comets without distinct heads.

All the operations were kept in the dark. All the tests performed in duplicate were repeated a minimum of three times.

\section{Statistical analyses}

To look for differences between the groups, the statistical significance was assessed by the $t$-test for dependent samples. Data were reported as means \pm standard error of the mean (SEM) and values of $P<.05$ were considered to be statistically significant.

\section{RESULTS}

The standard alkaline and Fpg-modified comet assay version evidenced an increase in \%TDNA in runners, compared with the controls, as shown in Table 2. The data also showed that the level of 8-oxo-dG was higher in all the enrolled runners than in the sedentary controls.

However, there was a high inter-individual variability among runners' values measured by standard alkaline and/or neutral comet assay. To better highlight the individual differences, we chose to distribute the data (\%TDNA values) of each runners' group into five different arbitrarily chosen classes (from I to V), corresponding to different ranges of \%TDNA values as reported in the Materials and Methods section.

This representation allowed us to evidence that in eight runners (group A), among the 25 enrolled subjects, almost all nucleoids were included in the highest classes of damage (from III to V) (Fig. 2a). In the same runners, high levels of double strand breaks (DSBs) were evidenced by neutral comet assay (Fig. 2c).

The addition of $100 \mu \mathrm{M}$ RESV to the samples of group A exacerbated DNA damage, augmenting in each subject the number of nucleoids in IV/V classes and in 
Table 2. Total and Oxidative DNA Damage Measured by Alkaline and Fpg Comet Assay in Runners' Blood Samples and in Control Sedentary Subjects

\begin{tabular}{lcc}
\hline Comet assay versions & Control & Runners \\
\hline $\mathrm{pH}>13$ & $15.8 \pm 0.85$ & $26.4 \pm 1.20^{*}$ \\
$\mathrm{Break} / 10^{9} \mathrm{Da}$ & 0.434 & 0.7905 \\
$\mathrm{pH}=12.1$ & $14.1 \pm 0.90$ & $21.8 \pm 1.09^{*}$ \\
$\quad$ Buffer treated & 0.32 & 0.6262 \\
$\mathrm{Break} / 10^{9} \mathrm{Da}$ & $19.5 \pm 1.10$ & $33.8 \pm 1.84^{* * * *}$ \\
$\mathrm{pH}=12.1$ & & \\
$\quad$ Fpg treated & 0.527 & 1.0695 \\
Break $/ 10^{9} \mathrm{Da}$ & 0.21 & 0.4433 \\
$\begin{array}{l}\text { FPG sites } \\
\quad\left(\text { Break } / 10^{9} \mathrm{Da}\right)\end{array}$ & 0.127 & 0.270 \\
8-oxo-dG $/ 10^{6} \mathrm{dG}$ &
\end{tabular}

Values are expressed as mean \pm standard error of the mean. The results expressed as \% TDNA are also converted into (i) breaks $/ 10^{9} \mathrm{Da}$ using for calculation of DNA break frequencies the calibration curve reported by Collins et al., ${ }^{23}$ and (ii) 8-oxo-dG/10 $10^{6} \mathrm{dG}$ using as conversion factor 18 -oxoGua $/ 10^{9} \mathrm{Da}$ is equivalent to 18 -oxo-Gua/ $0.61 \times 10^{6}$ Gua as reported by Griffiths et al. ${ }^{24}$

${ }^{*} P<.001$ : significant versus correspondent control values at $\mathrm{pH}>13$ and/or $\mathrm{pH} 12.1$ (buffer and Fpg).

$* * P<.001$ : significant versus correspondent buffer values.

\%TDNA, percentage of damaged DNA in the tail of the comet.

III/IV/V for alkaline and neutral assay, respectively (Fig. $2 b, d)$.

The other 17 runners (group B) showed a large percentage of nucleoids in classes I and II (Fig. 3a). The presence of DSBs, as revealed by neutral comet assay, was very low. In this group of runners, RESV was able to ameliorate DNA status (Fig. 3b, d).

In view of the just discussed results, we chose to treat group B subjects ( $n=17$ athletes), showing low DNA damage level, with $\mathrm{H}_{2} \mathrm{O}_{2}$ alone or combined with RESV and to examine their effects by standard alkaline and neutral versions.

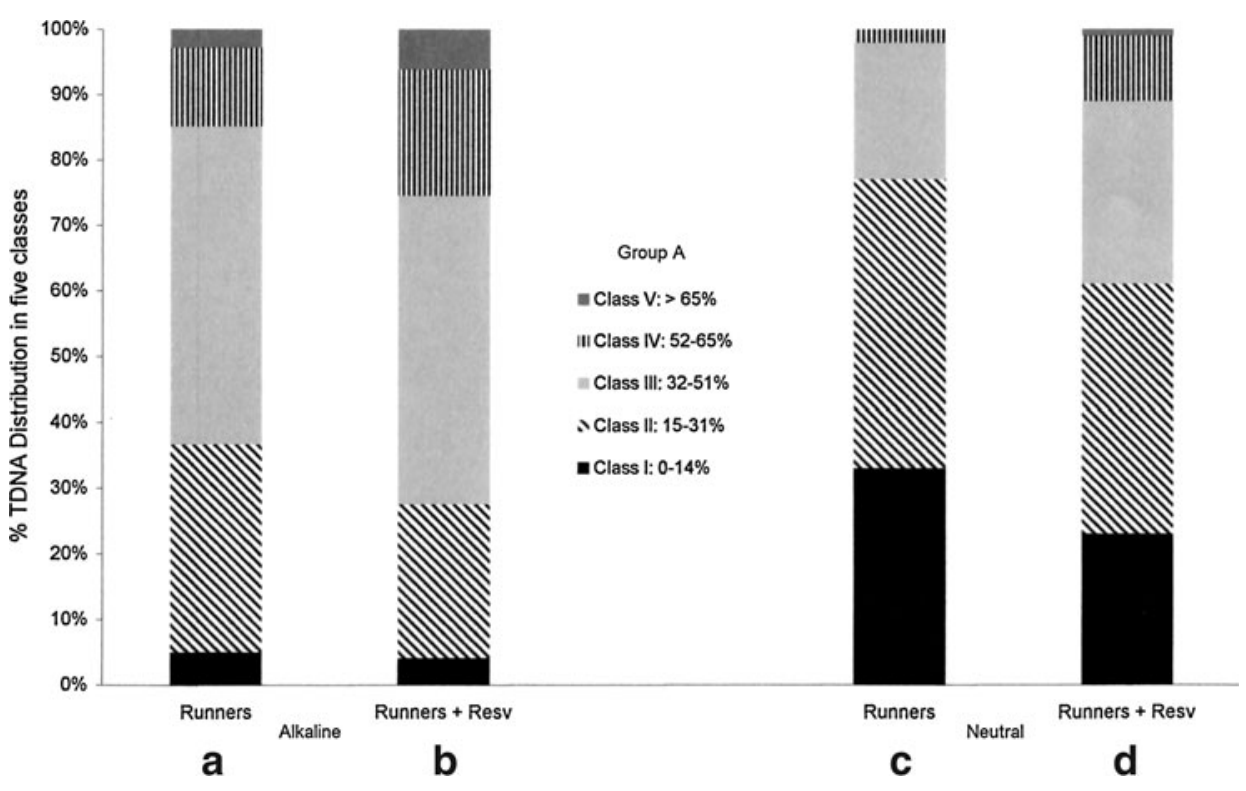

FIG. 2. Distribution of DNA damage for Group A, expressed as five different ranges of percentage of damaged DNA in the tail of the comet (\%TDNA; classes $\mathrm{I}-\mathrm{V}$ as in the Materials and Methods section). Values reported in each class represent the mean of data obtained from eight athletes. Alkaline (a, b; $\mathrm{pH}>13)$ and neutral (c, d; $\mathrm{pH} 8)$ comet assay on runners' whole blood cells alone or agarose embedded treated with $100 \mu \mathrm{M}$ resveratrol. 


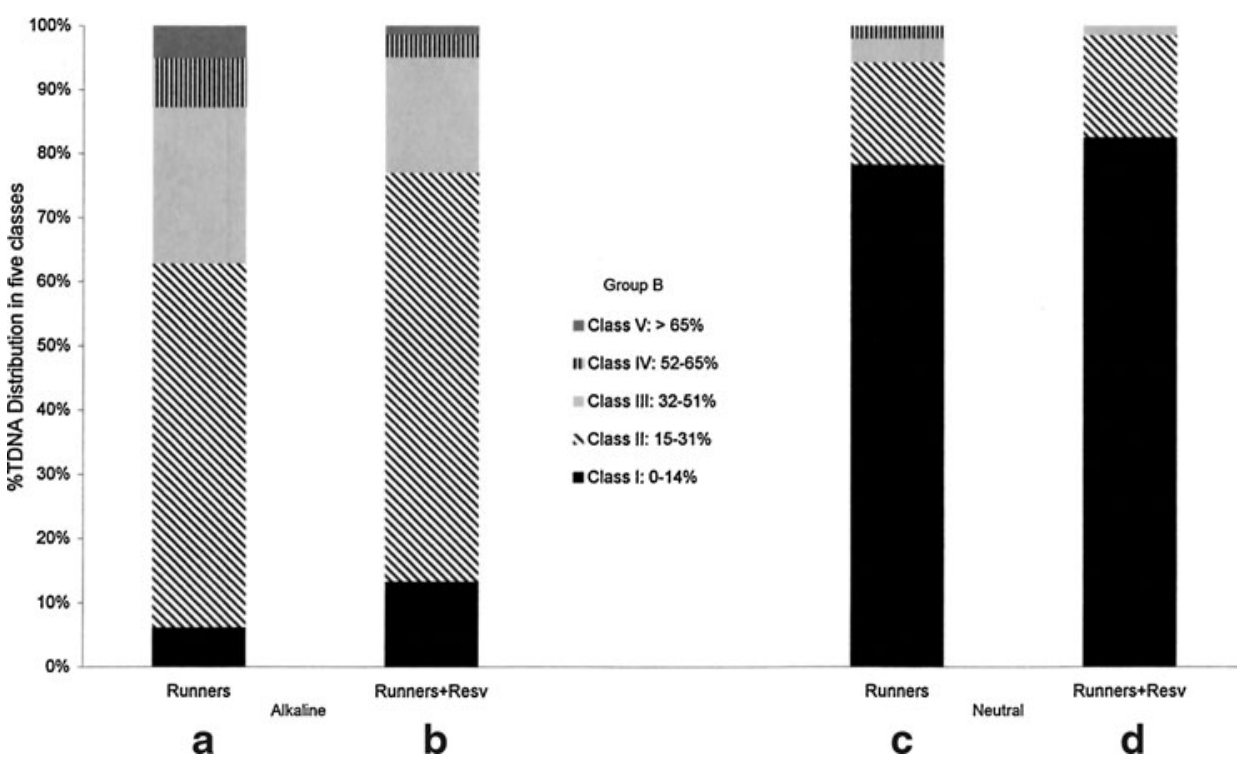

FIG. 3. Distribution of DNA damage for Group B, expressed as five different ranges of \%TDNA (classes $\mathrm{I}-\mathrm{V}$ as in Materials and Methods section). Values reported in each class represent the mean of data obtained from 17 athletes. Alkaline (a, b; $\mathrm{pH}>13$ ) and neutral (c, d; pH 8) comet assay on runners' whole blood cells alone or agarose embedded treated with $100 \mu \mathrm{M}$ resveratrol. leukocytes. These cells are good indicators of systemic situation but may reflect changes partially at the tissue level. ${ }^{11-13}$

Many researchers have studied DNA damage on white blood cells (WBCs), purified lymphocytes, as well as on whole blood cells, the latter today being preferred to lymphocytes, in order to avoid the artefacts occurring during isolation of cell types. ${ }^{13,21}$ Literature data warn against the use of whole blood cells in in vitro studies, because of the possible interference of red blood cells (RBCs) with some treatments and/or the possible contribution of catalase and glutathione peroxidise activities in suppressing DNA damaging activity elicited by various molecules, such as $\mathrm{H}_{2} \mathrm{O}_{2} \cdot{ }^{25}$ Furthermore, another limitation in utilizing WBCs in human studies is due to the wide variability in number, composition, and/or antioxidant capacity of WBCs, factors that could make interpreting the results difficult. ${ }^{25}$ In our opin- ion, this obstacle may be overcome by the advantage of single-cell comet assay that permits integrating/evaluating the effects elicited by the treatments on the different types of blood cells. However, our experience with WBCs, utilizing typical and atypical comet assay versions, confirms that whole blood cells, if opportunely treated, maybe preferred to lymphocytes. ${ }^{9,14,21}$ Conversely to Andreoli et al.,${ }^{26}$ in fact, we observed that the treatment with $200 \mu \mathrm{M} \mathrm{H}_{2} \mathrm{O}_{2}$ at $4^{\circ} \mathrm{C}$ for $20 \mathrm{~min}$ on agarose-embedded whole blood cells (atypical comet assay) was able to induce DNA damage in the runners' white cells, confirming that interference between treatments in situ and RBCs could be bypassed using adequate concentrations of substances.

Various researchers have also demonstrated the efficacy of some antioxidant molecules in reducing/preventing DNA damage or oxidative stress in athletes. However, these

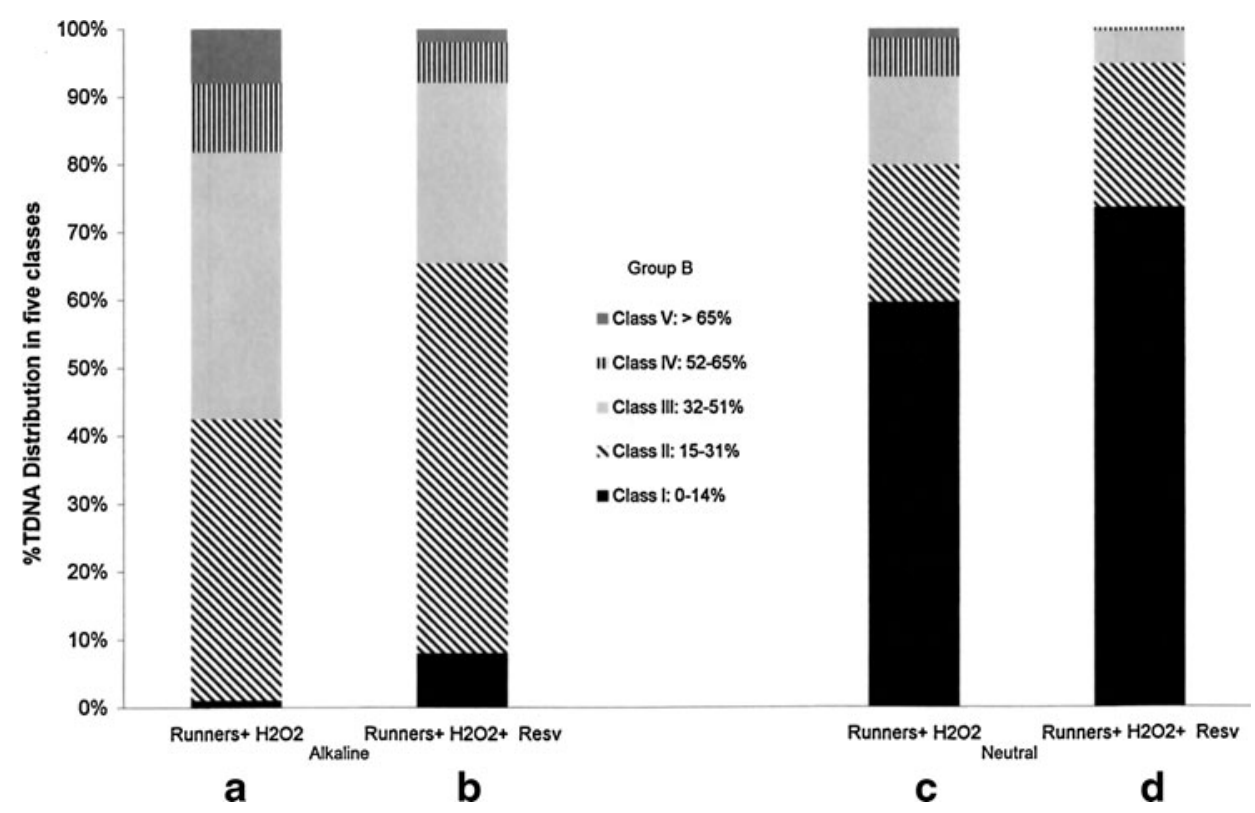

FIG. 4. Distribution of DNA damage for Group B, expressed as five different ranges of \% TDNA (classes $\mathrm{I}-\mathrm{V}$ as in Materials and Methods section). Values reported in each class represent the mean of data obtained from 17 athletes. Alkaline (a, b; pH>13) and neutral (c, d; $\mathrm{pH}$ 8) comet assay on runners' agaroseembedded cells treated with $\mathrm{H}_{2} \mathrm{O}_{2}$ $200 \mu \mathrm{M}$ and/or $\mathrm{H}_{2} \mathrm{O}_{2} \quad 200 \mu \mathrm{M}$ plus $100 \mu \mathrm{M}$ resveratrol. 
molecules seem to be effective in one cellular system but may fail to protect other systems, in which they may induce a damage. ${ }^{7-9}$ This dual response may depend on individual lifestyle and on genetic profile, but also on the different molecule concentrations used in the treatment, evidencing the pleiotropic activity of certain antioxidants, as it may be for RESV..$^{20}$ In our experimental conditions RESV in vitro treatment reduced DNA damage in only 17 of the 25 runners who exhibited a low percentage of blood cells falling into III, IV, and V classes (Fig. 3). Recently Moller and Loft ${ }^{27}$ indicate that supplementation with antioxidants in sedentary subjects had little effect on DNA damage and a protective effect only in the presence of a stressor. We treated Group B runners' blood cells with $\mathrm{H}_{2} \mathrm{O}_{2}$ as the stressor, observing a protective effect elicited by RESV.

Considering our results, we hypothesize that positive effects exerted by RESV in these subjects, having moderate basal damage and low DSBs level, maybe mediated by activation of cellular repair enzyme machinery, since agaroseembedded cells are able to maintain the efficient cellular enzymatic activities. This response may be due to a direct interaction between the phytoalexin and oxidized DNA bases (i.e., 8-oxo-guanidine), or to a possible direct antioxidant effect of RESV on cellular ROS production. When the stilbene was sequentially added to $\mathrm{H}_{2} \mathrm{O}_{2}$, it switched off the production of ROS, "quenching" $\mathrm{H}_{2} \mathrm{O}_{2}$.

Conversely, we observed that RESV behaved as a DNA damaging agent in Group A (eight runners) having per se a high percentage of nucleoids in high classes of damage, as well as high level of DSBs (Fig. 2). This type of damage usually arises during DNA repair and recombination, and sometimes leads to chromosomal aberrations, breaks, and translocations as well as oncogenic transformations. ${ }^{20,28}$ These athletes, each di per se, could be in an oxidative stress condition due to either a deficiency in some antioxidant systems or nonfunctioning DNA repair systems. In this instance, we speculate that RESV may be unable to scavenge radical $\mathrm{OH}^{*}$, mainly responsible for oxidative DNA modifications. In contrast, RESV can promote increased oxidative DNA damage, directly exerting its DNA-cleavage activity, an effect usually observed in the presence of some ions such as $\mathrm{Cu}$ and $\mathrm{Fe}^{28,29}$ Also, the lack of protective effects by RESV in runners maybe related to elevated blood levels of ascorbic acid, as already demonstrated. ${ }^{11}$

Our research confirms (i) the flexibility of the different comet assay versions in measuring different parameters, useful in performing a targeted therapeutic intervention; and (ii) the double-face behavior of resveratrol $(100 \mathrm{mM}$ in vitro), which switches from antioxidant to pro-oxidant. Our findings on stilbene suggest that its activity is dependent not only on the type of cells/tissue, concentrations/times of treatment, as reported, but also on individual DNA status and probably on the subjects' concentration of some metal ions $\left(\mathrm{Cu}^{+}\right.$and $\left.\mathrm{Fe}\right)$.

Our results encourage the use of comet assay and underline "the good, the bad, and the ugly" 30 properties of resveratrol, and/or probably of its metabolites. In addition, they point out the need for a greater control in the wide use of some micronutrients as diet supplements, in particular when the objective is to ameliorate the athletes' performance.

It is important to take into account the well-known interindividual variability, both at basal level and in response to treatment, by monitoring the level of oxidative status through appropriate testing before a daily intake of diet supplements is commenced.

\section{ACKNOWLEDGMENT}

This work was supported by the grant of MIUR-Ateneo (60\%) (to M.R.).

\section{AUTHORS' CONTRIBUTIONS}

The authors' responsibilities were as follows: B.T., S.G., and S.S. conducted the experiments and collected the data; G.M. supported B.T. in analyzing data and in manuscript revision; M.F. utilized the COMET software, acquiring data and elaborating statistical data; M.R. designed the study, analyzed data, supervised its collection, and wrote the manuscript, whose revision was collegial.

\section{AUTHOR DISCLOSURE STATEMENT}

The authors declare that they have no competing financial interests.

\section{REFERENCES}

1. Zorov DB, Bannikova SY, Belousov VV, Vyssokikh MY, Zorova LD, Isaev NK, Krasnikov BF, Plotnikov EY: Reactive oxygen and nitrogen species: Friends or foes? Biochemistry (Mosc) 2005;70:215-221.

2. Oliveira BF, Nogueira-Machado JA, Chaves MM: The role of oxidative stress in the aging process. Sci World J 2010;10:1121-1128.

3. Cataldi A: Cell responses to oxidative stressors. Curr Pharm Des 2010;16:1387-1395.

4. Cesari M, Kritchevsky SB, Leeuwenburgh C, Pahor M: Oxidative damage and platelet activation as new predictors of mobility disability and mortality in elders. Antioxid Redox Signal 2006;8:609-619.

5. Goto S, Naito H, Kaneko T, Chung HY, Radák Z: Hormetic effects of regular exercise in aging: Correlation with oxidative stress. Appl Physiol Nutr Metab 2007;32:948-953.

6. Bastaki M, Huen K, Manzanillo P, Chande N, Chen C, Balmes JR, Tager IB, Holland N: Genotype-activity relationship for Mnsuperoxide dismutase, glutathione peroxidase 1 and catalase in humans. Pharmacogenet Genomics 2006;16:279-286.

7. Radak Z, Chung HY, Goto S: Systemic adaptation to oxidative challenge induced by regular exercise. Free Radic Biol Med 2008;44:153-159.

8. Urso ML, Clarkson PM: Oxidative stress, exercise, and antioxidant supplementation. Toxicology 2003;189:41-54.

9. Di Giacomo C, Acquaviva R, Sorrenti V, Vanella A, Grasso S, Barcellona ML, Galvano F, Vanella L, Renis M: Oxidative and antioxidant status in plasma of runners: Effect of oral supplementation with natural antioxidants. J Med Food 2009;12:145-150.

10. Bernstein C, Bernstein H, Payne CM, Garewal H: DNA repair/proapoptotic dual-role proteins in five major DNA repair pathways: Fail-safe protection against carcinogenesis. Mutat Res 2002;511: $145-178$. 
11. Mastaloudis A, Yu TW, O’Donnell RP, Frei B, Dashwood RH, Traber MG: Endurance exercise results in DNA damage as detected by the comet assay. Free Radic Biol Med 2004;36:966975.

12. Malayappan B, Garrett TJ, Segal M, Leeuwenburgh C: Urinary analysis of 8-oxoguanine, 8-oxoguanosine, fapy-guanine and 8oxo-2'-deoxyguanosine by high-performance liquid chromatography-electrospray tandem mass spectrometry as a measure of oxidative stress. J Chromatogr A 2007;1167:54-62.

13. Giovannelli L, Pitozzi V, Riolo S, Dolara P: Measurement of DNA breaks and oxidative damage in polymorphonuclear and mononuclear white blood cells: A novel approach using the comet assay. Mut Res 2003;538:71-80.

14. Tigano C, Tomasello B, Pulvirenti V, Ferrito V, Copat C, Carpinteri G, Mollica E, Sciacca S, Renis M: Assessment of environmental stress in Parablennius sanguinolentus (Pallas, 1814) of the Sicilian Ionian coast. Ecotoxicol Environ Saf 2009;72:1278-1286.

15. Renis M, Calandra L, Scifo C, Tomasello B, Cardile V, Vanella L, Bei R, La Fauci L, Galvano F: Response of cell cycle/stressrelated protein expression and DNA damage upon treatment of CaCo2 cells with anthocyanins. Br J Nutr 2008;100:27-35.

16. Aruoma OI: Antioxidant actions of plant foods: Use of oxidative DNA damage as a tool for studying antioxidant efficacy. Free Radic Res 1999;30:419-427.

17. De Salvia R, Festa F, Ricordy R, Perticone P, Cozzi R: Resveratrol affects in a different way primary versus fixed DNA damage induced by $\mathrm{H}(2) \mathrm{O}(2)$ in mammalian cells in vitro. Toxicol Lett 2002;135:1-9.

18. Leonard SS, Xia C, Jiang BH, Stinefelt B, Klandorf H, Harris GK, Shi X: Resveratrol scavenges reactive oxygen species and effects radical-induced cellular responses. Biochem Biophys Res Commun 2003;309:1017-1026.

19. Russo A, Palumbo M, Aliano C, Lempereur L, Scoto G, Renis M: Red wine micronutrients as protective agents in Alzheimerlike induced insult. Life Sci 2003;72:2369-2379.
20. de la Lastra CA, Villegas I: Resveratrol as an antioxidant and pro-oxidant agent: Mechanisms and clinical implications. Biochem Soc Trans 2007;35:1156-1160.

21. Grasso S, Siracusa L, Spatafora C, Renis M, Tringali C: Hydroxytyrosol lipophilic analogues: Enzymatic synthesis, radical scavenging activity and DNA oxidative damage protection. Bioorg Chem 2007;35:137-152.

22. Wojewòdzka M, Buraczewska I and Kruszewski M: A modified neutral comet assay: Elimination of lysis at high temperature and validation of the assay with anti-single-stranded DNA antibody. Mutat Res 2002;518:9-20.

23. Collins AR, Dusinska M, Gedik CM, Stetina R: Oxidative damage to DNA; do we have a reliable biomarker? Environ Health Perspect 1996;104:465-469.

24. Griffiths HR, Moller L, Bartosz G, Bast A, Bertoni-Freddari C, Collins A, Cooke M, Coolen S, Haenen G, Hoberg AM, Loft S, Lunec J, Olinski R, Parry J, Pompella A, Poulsen H, Verhagen H, Astley SB: Biomarkers. Mol Aspects Med 2002;23:101-208.

25. Chuang $\mathrm{CH}, \mathrm{Hu}$ ML: Use of whole blood directly for single-cell gel electrophoresis (comet) assay in vivo and white blood cells for in in vitro assay. Mutat Res 2004;564:75-82.

26. Andreoli C, Rossi S, Leopardi P, Crebelli R: DNA damage by hydroquinone in human white blood cells: Analysis by alkaline single-cell gel electrophoresis. Mutat Res 1999;438:37-45.

27. Moller P, Loft S: Oxidative DNA damage in human white blood cells in dietary antioxidant intervention studies. Am J Clin Nutr 2002;76:303-310.

28. Ahmad A, Farhan AS, Singh S, Hadi SM: DNA breakage by resveratrol and $\mathrm{Cu}(\mathrm{II})$ : Reaction mechanism and bacteriophage inactivation. Cancer Lett 2000;54:29-37.

29. Kavas GO, Aribal-Kocatürk P, Büyükkağnici DI: Resveratrol: Is there any effect on healthy subject? Biol Trace Elem Res 2007;118:250-254.

30. Zhou S, Koh HL, Gong ZY, Lee EJ: Herbal bioactivation: The good, the bad and the ugly. Life Sci 2004;74:935-968. 